\title{
KARAKTERISTIK ORGANIOLEPTIK OTAK-OTAK IKAN YANG DIBERI EDIBLE COATING KARAGINAN DENGAN PENAMBAHAN ASAP CAIR
}

\author{
Eka Irma Q. Bariah ${ }^{1}$, S. Berhimpon ${ }^{2}$, Eunike L. Mongi ${ }^{3}$ \\ 1) Mahasiswa pada Program Studi Teknologi Hasil Perikanan FPIK Unsrat Manado \\ ${ }^{2)}$ Staf pengajar pada Program Studi Teknologi Hasil Perikanan FPIK Unsrat Manado \\ Email : eka.baria@yahoo.com
}

\begin{abstract}
Edible coating is a new type of packaging made of biopolymer. The advantages of edible coating is enable to protect the food product, the original appearance of the product can be maintained and the product can be eaten as well as environmentally friendly. The study aim was to look at the organoleptic characteristics of fish cake coated with edible coating of carrageenan were given a liquid smoke. The treatments given were variation of carrageenan concentration i,e. $0 \%, 1 \%, 1,5 \%, 2 \%, 2,5 \%$, $3 \%$. The experiment was designed using a Completely Randomized Design (CRD). To determine the effect of treatments, the data were tested using organoleptical tests consists of hedonic and texture.

The results shown that hedonic test of the appearance and color of the raw sample have significant effect $(p>0,05)$, while the other test showed no significant effect $(p>0,05)$. However, the organoleptical score for taste, smell and texture shown a tendency that the fish cake coated, have higher score than without coated.
\end{abstract}

Keywords: $\quad$ Edible coating, Carrageenan, Fish cake, Liquid smoke.

\section{PENDAHULUAN}

Pangan merupakan kebutuhan dasar manusia. Pemenuhan pangan merupakan hak asasi setiap insan, sehingga pemerintah berkewajiban untuk menyediakan pangan secara cukup setiap waktu, aman, bermutu, bergizi, dan beragam dengan harga yang terjangkau oleh daya beli masyarakat. Untuk itu perlu sebuah sistem keamanan pangan yang memberikan perlindungan bagi pihak produsen (pengusaha) maupun konsumen (masyarakat).

Seiring dengan perkembangan teknologi, pemanfaatan rumput laut telah ditingkatkan antara lain sebagai bahan dasar pembuatan Edible coating dari produk ekstraksinya yaitu karaginan.

Penelitian yang dilakukan adalah untuk melihat karakteristik organoleptik otak-otak ikan yang dicoating dengan Edible coating dari karaginan yang diberi asap cair dibandingkan dengan yang tidak dicoating.

\section{METODOLOGI PENELITIAN}

\section{Bahan dan Alat}

Bahan baku yang digunakan untuk pembuatan Edible coating adalah karaginan, asap cair, lilin lebah, gliserol dan $\mathrm{NaOH}$, produk untuk aplikasi coating digunakan otak- otak ikan merk "Cham Seafood". Alat yang digunakan : Erlenmeyer, Beaker glass, Gelas ukur, Pipet, Spatula, Thermocouple, Hot plate, Kertas lakmus, Homogenizer stir, Timbangan. Bahan untuk Uji organoleptik : Otak-otak ikan, Roti, Buavita, Agua gelas. Alat : Piring kertas, Label, Tissue, Tusuk gigi, Lembar penilaian.

\section{Perlakuan}

Perlakuan konsentrasi yang terdiri dari 6 variabel, Setiap formulasi Edible coating dibuat dengan penambahan asap cair $0,8 \%$. Otak-otak ikan yang diuji organoleptik dengan perlakuan konsentrasi karaginan $(0 \%, 1 \%$, $1,5 \%, 2 \%, 2,5 \%, 3 \%$ ). Sebagai kontrol dipakai otak-otak ikan tanpa dicoating $(0 \%)$, ulangan dilakukan sebanyak 2 kali.

\section{Rancangan Percobaan}

Percobaan dirancang menggunakan rancangan acak lengkap (RAL). Untuk mengetahui pengaruh perlakuan maka data diuji menggunakan analisis keragaman. Jika hasil analisa menunjukkan signifikan maka data di uji lanjut menggunakan uji lanjut BNT (Hanafiah, 2002). 
Tata Laksana Penelitian

Pembuatan Edible coating

Proses pembuatan Edible coating dilakukan dengan penimbangan tepung karaginan sebanyak konsentrasi yang digunakan $(0 \%, 1 \%, 1,5 \%, 2 \%, 2,5 \%, 3 \%)$. Larutkan kedalam larutan asap cair $(0,8 \%)$ yang ditambahkan sebanyak $200 \mathrm{ml}$. Kemudian dipanaskan pada suhu $55^{\circ} \mathrm{C}$ selama 30 menit. larutan didinginkan sampai suhu $50^{\circ} \mathrm{C}$. Larutan ditambahkan $\mathrm{NaOH}$ hingga $\mathrm{pH}$-nya menjadi $\mathrm{pH}$ 7, kemudian dilakukan pengadukan dan dipanaskan kembali pada suhu $70^{\circ} \mathrm{C}$. Tambahkan gliserol sebanyak $1 \%$ dan lilin lebah sebanyak $0,4 \% \quad(\mathrm{v} / \mathrm{v})$. Suspensi dihomogenkan dan dipanaskan selama 25 menit, selanjutnya dilakukan degassing (75 Kpa, 20 menit). Hasil yang didapatkan itulah larutan Edible coating (santoso dkk, 2007) yang telah dimodifikasi.

\section{Parameter yang diamati dan pengukurannya}

Parameter yang diukur adalah pengujian organoleptik yang terdiri dari pengujian hedonik dan pengujian tekstur.

\section{Aplikasi Edible Coating Karaginan Pada Otak-Otak Ikan}

Pemberian Edible coating pada otakotak ikan dapat dilihat pada Gambar 1.

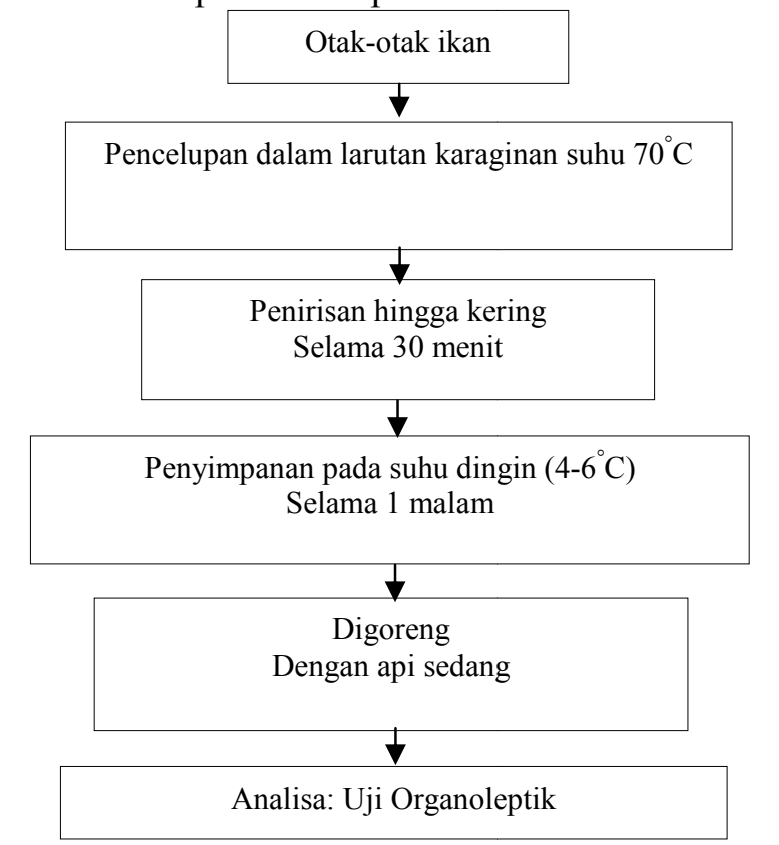

Gambar 1. Diagram Alir Aplikasi Edible Coating Karaginan pada Otak-otak Ikan (Riyanto, 2006) yang telah dimodifikasi.
Pengujian organoleptik dilakukan terhadap penampakan, warna, bau, cita rasa dan tekstur sesuai uji kesukaan, (Hedonik) (Berhimpon dkk, 2002). Dengan Standar Nasional Indonesia (SNI- 01-2346-2006). Pengujian dilakukan dengan menggunakan 17 panelis semi terlatih, dimana tiap panelis disajikan sampel dan diberikan lembar penilaian. Panelis akan memberikan penilaian di dalam lembar penilaian berdasarkan kriteria dan spesifikasi yang tersedia pada lembar penilaian. Pengujian tekstur (Borderias dkk, dalam Berhimpon 1990) Pengukuran menggunakan 17 panelis semi terlatih untuk konsep dasar dari analisis deskriptif dan terminologi. Dua karakteristik yang diukur antara lain: karakteristi awal (Wateriness, Firmness dan Elasticity) dan karakteristik kedua (Hardness dan Juiciness).

\section{HASIL DAN PEMBAHASAN}

\section{Uji Hedonik Otak-otak Ikan (Sampel Mentah) \\ Penampakan}

Rata-rata penilaian hedonik terhadap penampakan otak-otak ikan yang mentah untuk yang tidak dicoating adalah 5,8, sedangkan yang dicoating ada pada kisaran 6,1-7,6 yaitu kisaran nilai agak suka sampai suka.

Analisis keragaman terhadap penampakan menunjukkan bahwa perlakuan konsentrasi karaginan memberikan pengaruh yang nyata $(\mathrm{P}>0.05)$.

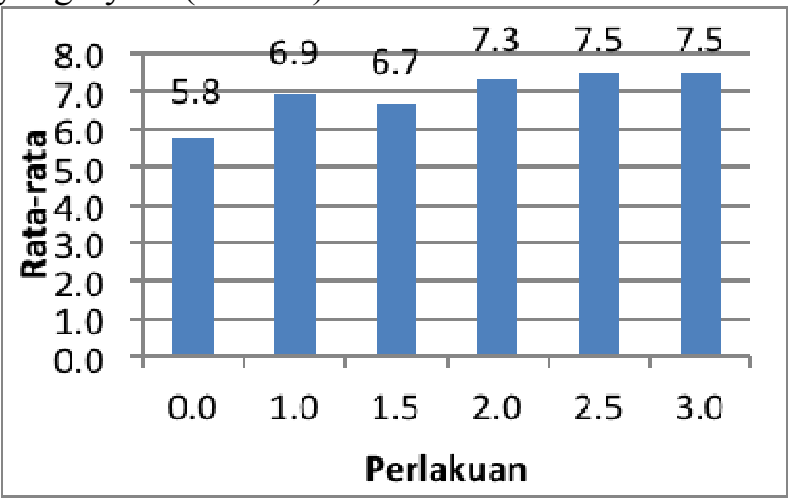

\section{Gambar 2. Kesukaan panelis terhadap penampakan (Sampel Mentah) otak- otak ikan yang dicoating dan tanpa coating.}

Dari grafik diatas menunjukkan bahwa nilai kesukaan panelis terhadap nilai penampakan otak-otak ikan yang tertinggi ada pada perlakuan karaginan dengan konsentrasi $3 \%$. Sedangkan terendah ada pada perlakuan 
$0 \%$ tanpa coating. Semakin tinggi konsentrasi, semakin tinggi nilai kesukaan panelis terhadap penampakan otak-otak ikan.

\section{Warna}

Rata- rata penilaian hedonik terhadap warna otak-otak ikan yang mentah untuk yang tidak dicoating adalah 5,6 sedangkan yang dicoating ada pada kisaran 6,6-7,6 yaitu kisaran nilai agak suka sampai suka.

Analisis keragaman terhadap warna menunjukkan bahwa perlakuan konsentrasi karaginan memberikan pengaruh nyata $(\mathrm{P}>0,05)$.

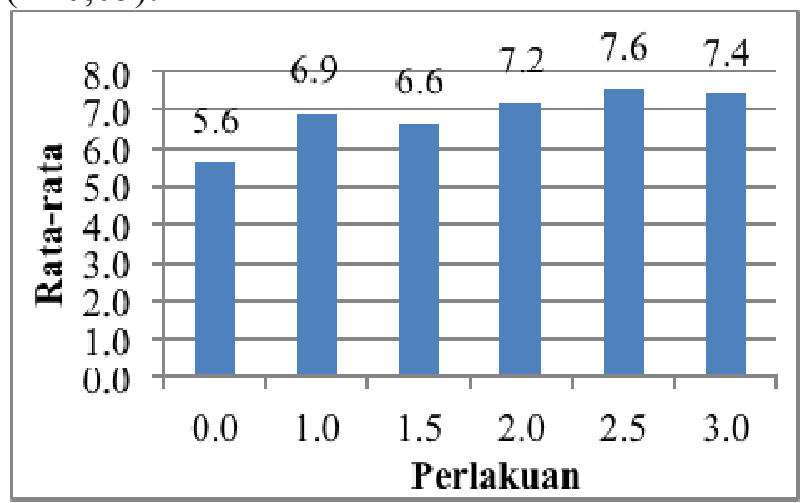

Gambar 3. Kesukaan panelis terhadap warna (Sampel Mentah) otak-otak ikan yang dicoating dan tanpa coating.

Dari grafik diatas menunjukkan bahwa nilai kesukaan panelis terhadap nilai warna otak-otak ikan yang tertinggi ada pada perlakuan karaginan dengan konsentrasi $2.5 \%$ sedangkan terendah ada pada perlakuan $0 \%$ tanpa coating. . Pada perlakuan karaginan semakin tinggi konsentrasi karaginan semakin tinggi nilai kesukaan warna terhadap otak-otak ikan.

\section{Bau}

Rata- rata penilaian hedonik terhadap bau otak-otak ikan yang mentah untuk yang tidak dicoating adalah 5,2 sedangkan yang dicoating ada pada kisaran 6,4-7,1 yaitu kisaran nilai agak suka sampai suka.

Analisis keragaman terhadap bau menunjukan bahwa perlakuan konsentrasi karaginan memberikan pengaruh tidak nyata $(\mathrm{P}>0,05)$. Namun demikian Gambar 5 menunjukkan bahwa makin tinggi konsentrasi, makin tinggi nilai bau.

Dari grafik 4 menunjukkan bahwa nilai kesukaan panelis terhadap nilai bau otak-otak ikan yang tertinggi ada pada perlakuan karaginan dengan konsentrasi $2.5 \%$ sedangkan terendah ada pada perlakuan $0 \%$ tanpa coating.

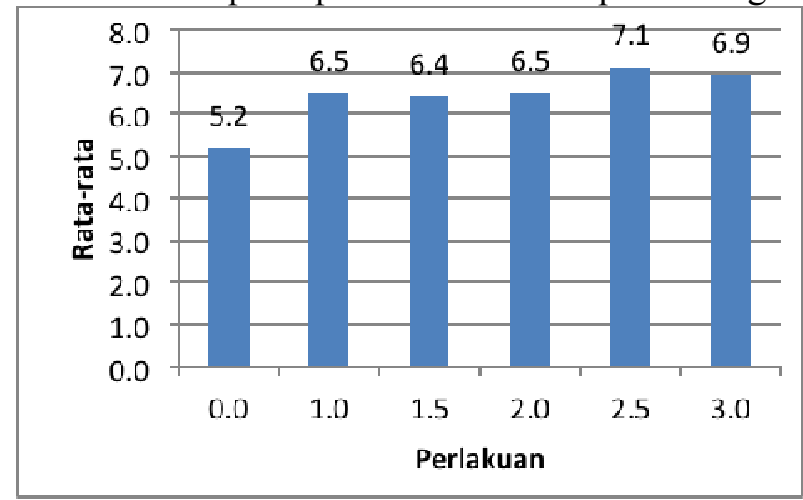

Gambar 4. Kesukaan panelis terhadap bau (Sampel Mentah) otak-otak ikan yang dicoating dan tanpa coating.

\section{Uji Hedonik Otak-otak Ikan Yang Goreng Penampakan}

Rata-rata penilaian hedonik terhadap penampakan otak-otak ikan yang goreng untuk yang tidak dicoating adalah 7,1 sedangkan yang dicoating ada pada kisaran 6,9-7,3 yaitu kisaran nilai agak suka sampai suka.

Analisis keragaman terhadap penampakan menunjukkan bahwa perlakuan konsentrasi karaginan memberikan pengaruh tidak nyata $(\mathrm{P}>0,05)$.

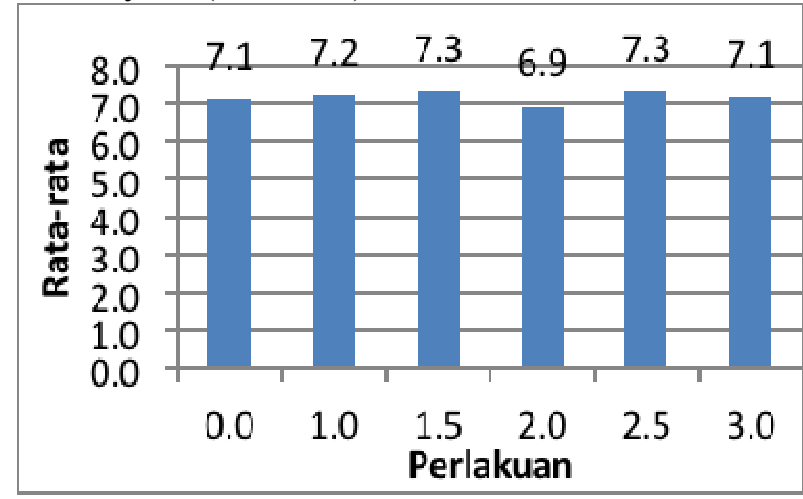

\section{Gambar 5. Kesukaan panelis terhadap penampakan otak-otak ikan yang dicoating dan tanpa coating dan digoreng.}

Dari grafik di atas menunjukkan bahwa nilai kesukaan panelis terhadap nilai penampakan otak-otak ikan yang tertinggi ada pada perlakuan karaginan dengan konsentrasi $1.5 \%$. Sedangkan terendah ada pada perlakuan $2 \%$.

\section{Warna}

Rata-rata penilaian hedonik terhadap warna otak-otak ikan yang goreng untuk yang tidak dicoating adalah 5,6 sedangkan yang 
dicoating ada pada kisaran 6'6-7,6 yaitu kisaran nilai agak suka sampai suka.

Analisis keragaman terhadap warna menunjukan bahwa perlakuan konsentrasi karaginan tidak berpengaruh nyata $(\mathrm{P}>0,05)$.

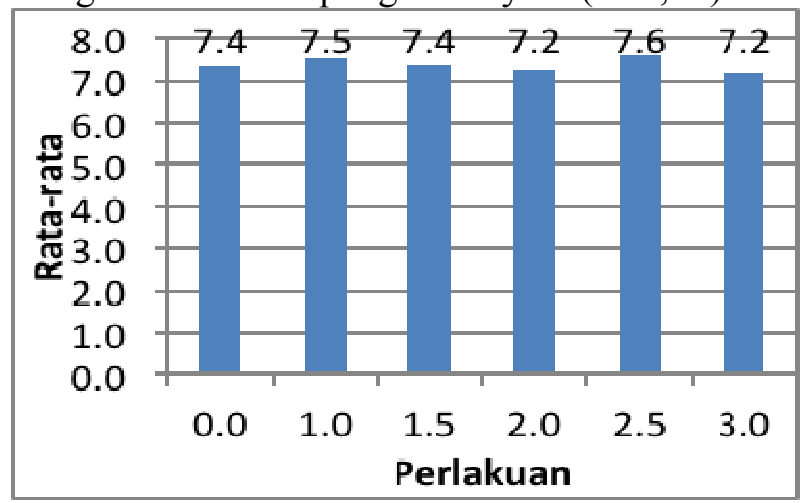

Gambar 6. Kesukaan panelis terhadap warna yang dicoating dan tanpa coating dan digoreng.

Grafik diatas menunjukkan bahwa nilai kesukaan panelis terhadap nilai warna otakotak ikan yang tertinggi ada pada perlakuan karaginan dengan konsentrasi $2.5 \%$ sedangkan terendah ada pada perlakuan $3 \%$.

\section{Bau}

Rata-rata penilaian hedonik terhadap bau otak-otak ikan yang goreng untuk yang tidak dicoating adalah 7,5 sedangkan yang dicoating ada pada kisaran 6,9-7,8 yaitu kisaran nilai agak suka sampai suka.

Analisis keragaman terhadap bau menunjukkan bahwa perlakuan konsentrasi karaginan tidak berpengaruh nyata $(\mathrm{P}>0,05)$. Pada Gambar 8 menunjukkan bahwa makin tinggi konsentrasi, makin rendah nilai bau.

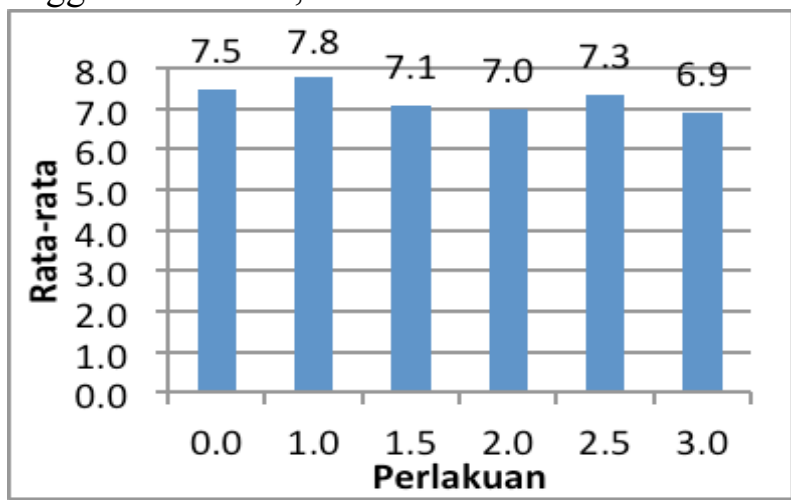

Gambar 7. Kesukaan panelis terhadap bau otak-otak ikan yang dicoating dan tanpa coating dan digoreng

Dari grafik diatas menunjukkan bahwa nilai kesukaan panelis terhadap nilai bau otakotak ikan yang tertinggi ada pada perlakuan karaginan dengan konsentrasi $1.0 \%$ sedangkan terendah ada pada perlakuan $3 \%$.

\section{Rasa}

Rata- rata penilaian hedonik terhadap rasa otak-otak ikan yang goreng untuk yang tidak dicoating adalah 7,3 sedangkan yang dicoating ada pada kisaran 6,7-7,6 yaitu kisaran nilai agak suka sampai suka.

Analisis keragaman terhadap rasa menunjukkan bahwa perlakuan konsentrasi karaginan tidak berpengaruh nyata $(\mathrm{P}>0,05)$.

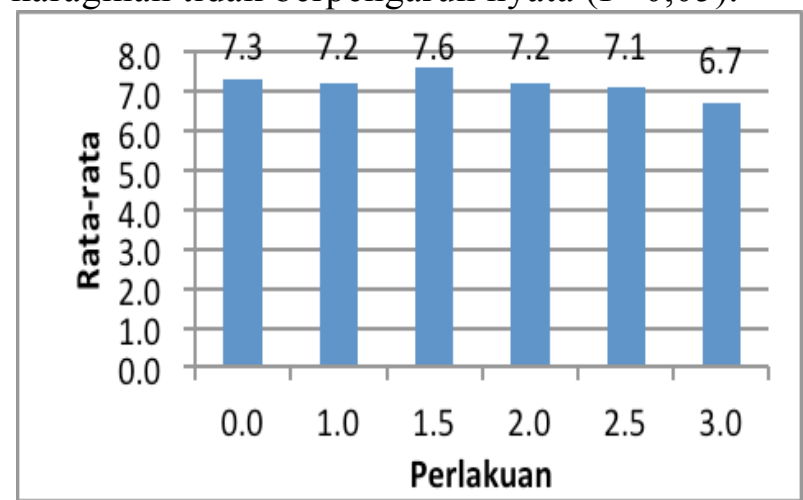

Gambar 8. Kesukaan panelis terhadap rasa otak-otak ikan yang dicoating dan tanpa coating dan digoreng.

Dari grafik diatas menunjukkan bahwa nilai kesukaan panelis terhadap nilai rasa otakotak ikan yang tertinggi ada pada perlakuan karaginan dengan konsentrasi $1.5 \%$ sedangkan terendah ada pada perlakuan $3.0 \%$

\section{Tekstur}

Rata- rata penilaian hedonik terhadap tekstur otak-otak ikan yang goreng untuk yang tidak dicoating adalah 6,9 sedangkan yang dicoating ada pada kisaran 7,1-7,4 yaitu pada kisaran nilai suka.

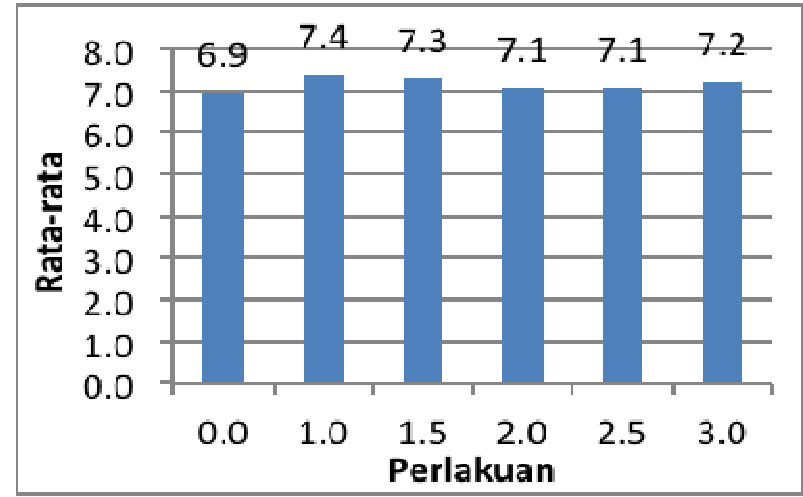

Gambar 9. Kesukaan panelis terhadap tekstur otak-otak ikan yang dicoating dan tanpa coating dan digoreng. 
Analisis keragaman terhadap tekstur menunjukan bahwa perlakuan konsentrasi karaginan tidak berpengaruh nyata $(\mathrm{P}>0,05)$.

Dari grafik diatas menunjukkan bahwa nilai kesukaan panelis terhadap nilai tekstur otak-otak ikan yang tertinggi ada pada perlakuan karaginan dengan konsentrasi $1.0 \%$ sedangkan terendah ada pada perlakuan $0.0 \%$ tanpa coating.

\section{Uji Tekstur Otak-otak Ikan Wateriness}

Rata- rata penilaian tekstur terhadap wateriness otak-otak ikan yang goreng untuk yang tidak dicoating adalah 4,6 sedangkan yang dicoating ada pada kisaran 4,5-5,0 yaitu pada kisaran mendekati netral sampai netral.

Analisis keragaman terhadap wateriness menunjukan bahwa perlakuan konsentrasi karaginan tidak berpengaruh nyata $(\mathrm{P}>0,05)$.

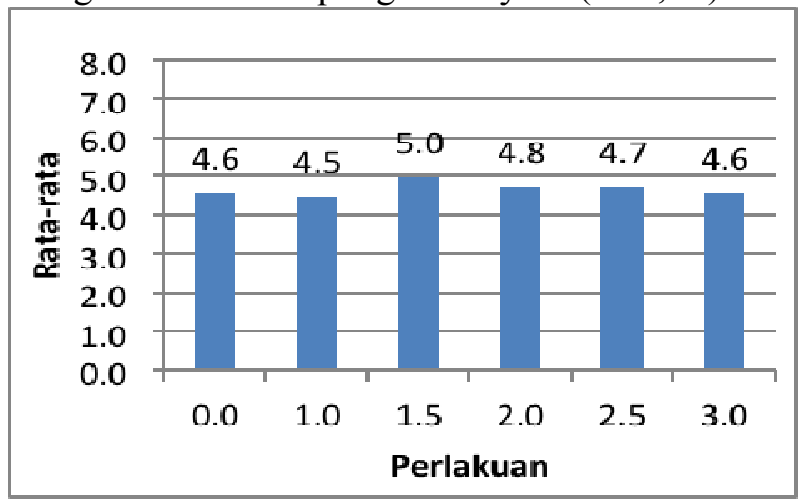

\footnotetext{
Gambar 10. Penilaian panelis terhadap wateriness otak-otak ikan yang dicoating dan tanpa coating.
}

Grafik diatas menunjukkan bahwa perlakuan dengan karaginan memiliki nilai wateriness lebih tinggi pada konsentrasi $1.5 \%$ dan terendah pada konsentrasi 1\%. Pada penelitian ini tidak di uji kadar air dari produk, tetapi Suryaningrum et al (2005) dalam pembuatan edible film dengan bahan hidrokoloid karaginan dan tapioka mempunyai nilai kadar air berkisar antara 12,87-17,34 \%.

\section{Firmness}

Rata- rata penilaian tekstur terhadap firmness otak-otak ikan yang goreng untuk yang tidak dicoating adalah 4,6 sedangkan yang dicoating ada pada kisaran 4,7-5,8 yaitu pada kisaran mendekati netral sampai netral.

Analisis keragaman terhadap firmness menunjukan bahwa perlakuan konsentrasi karaginan tidak berpengaruh nyata $(\mathrm{P}>0,05)$.

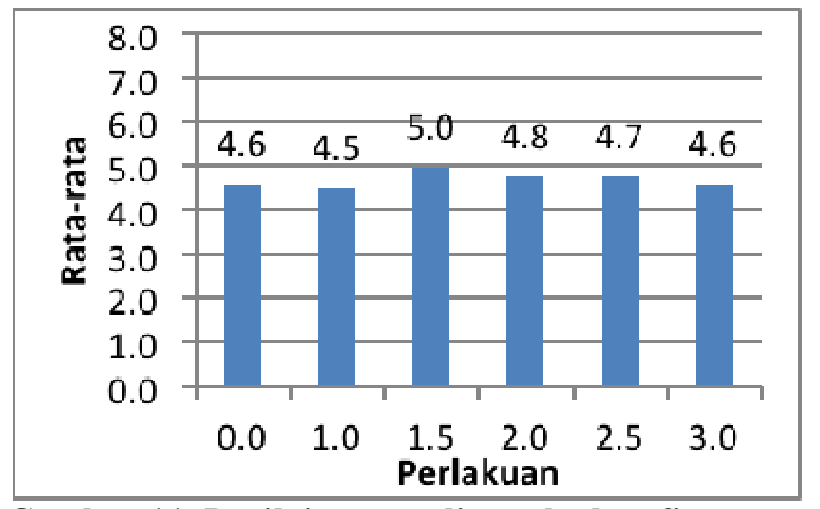

Gambar 11. Penilaian panelis terhadap firmness otak-otak ikan yang dicoating dan tanpa coating.

Grafik diatas menunjukkan bahwa perlakuan dengan karaginan memiliki nilai firmness lebih tinggi pada konsentrasi $1.5 \%$ dan terendah pada konsentrasi $1 \%$.

\section{Elasticity}

Rata-rata penilaian tekstur terhadap elasticity otak-otak ikan yang goreng untuk yang tidak dicoating adalah 4,8 sedangkan yang dicoating ada pada kisaran $5,2-5,8$ yaitu pada kisaran netral.

Analisis keragaman terhadap elasticity menunjukkan bahwa perlakuan konsentrasi karaginan tidak berpengaruh nyata $(p>0,05)$.

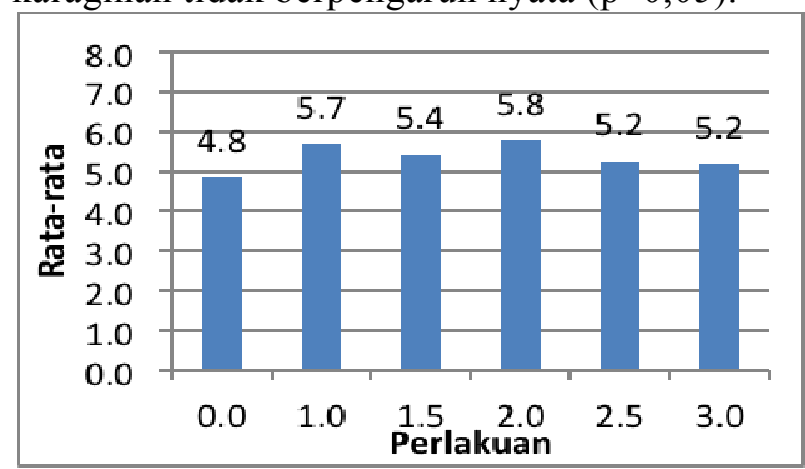

Gambar 12. Penilaian panelis terhadap elasticity otak-otak ikan yang dicoating dan tanpa coating.

Grafik diatas menunjukkan bahwa nilai elastisitas tertinggi pada konsentrasi $2 \%$ sedangkan nilai elastisitas terendah pada konsentrasi $0 \%$ tanpa coating.

\section{Hardness}

Rata- rata hasil uji tekstur terhadap hardness otak-otak ikan yang goreng untuk yang tidak dicoating adalah 5,1 sedangkan yang dicoating ada pada kisaran 4,8-5,4 yaitu kisaran nilai mendekati netral sampai netral. 
Analisis keragaman terhadap hardness menunjukan bahwa perlakuan konsentrasi karaginan tidak berpengaruh nyata $(\mathrm{P}>0,05)$.

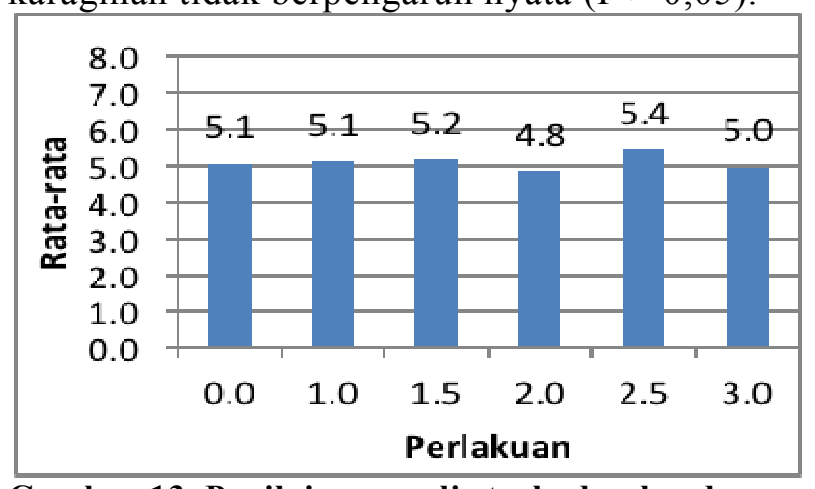

Gambar 13. Penilaian panelis terhadap hardnesss otak-otak goreng yang dicoating dan tanpa coating.

Grafik diatas menunjukkan bahwa nilai hardness tertinggi pada perlakuan karaginan $2.5 \%$ sedangkan hardness terendah pada perlakuan $2 \%$.

\section{Juiciness}

Rata- rata penilaian tekstur terhadap juiciness otak-otak ikan yang goreng untuk yang tidak dicoating adalah 4,9 sedangkan yang dicoating ada pada kisaran 5,3-5,9 yaitu kisaran nilai netral sampai lebih dari netral.

Analisis keragaman terhadap juiciness menunjukan bahwa perlakuan konsentrasi karaginan tidak berpengaruh nyata $(\mathrm{P}>0,05)$.

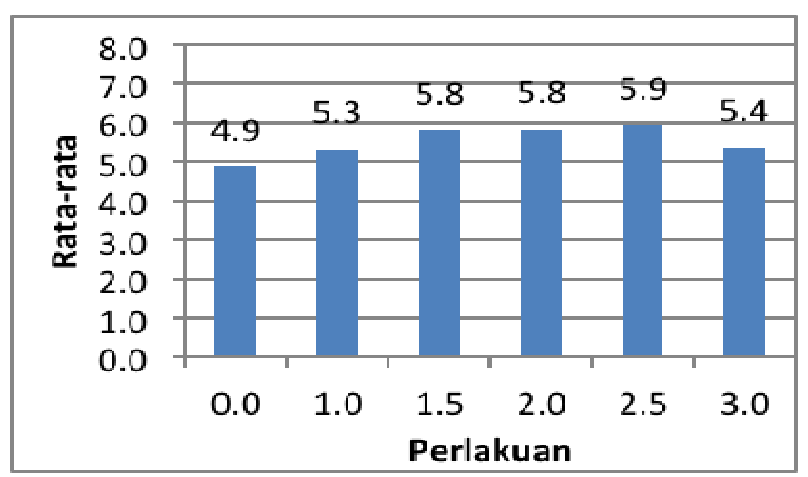

Gambar 14. Penilaian panelis terhadap juiciness otak-otak ikan yang dicoating dan tanpa coating.

Grafik diatas menunjukkan bahwa nilai juiciness tertinggi pada perlakuan karaginan $2,5 \%$ sedangkan juiciness terendah pada konsentrasi $0.0 \%$ tanpa coating.

\section{KESIMPULAN}

Pengaruh perlakuan konsentrasi karaginan pada Edible coating menunjukkan bahwa yang berbeda nyata hanya untuk pengaruh penampakan dan warna, sedangkan rasa, bau, dan tekstur tidak menunjukkan pengaruh yang nyata. Konsentrasi karaginan sebesar $1,5 \%$ pada uji rasa menunjukkan karakteristik terbaik karena lebih di sukai panelis. Konsentrasi karaginan sebesar 1\% pada uji bau menunjukkan karakteristik terbaik karena lebih di sukai panelis. Konsentrasi karaginan sebesar $1,5 \%$ pada uji tekstur menunjukkan karakteristik terbaik karena lebih di sukai panelis. Hasil penilaian tekstur terhadap wateriness otak-otak ikan yang dicoating menunjukkan karakteristik terbaik pada perlakuan $1,5 \%$. Firmness pada perlakuan $1,5 \%$ menunjukkan karakteristik terbaik. Elasticity pada perlakuan $2 \%$ menunjukkan karakteristik terbaik. Hardness pada perlakuan $2,5 \%$ menunjukkan karakteristik terbaik. Juiciness pada perlakuan $2,5 \%$ menunjukkan karakteristik terbaik.

\section{DAFTAR PUSTAKA}

Berhimpon S. 1990. Studies on salting and drying of yellowtail (Trachurus mecullochi nichols) Disertasi : 238-239, UNSW, Sydney

Berhimpon, S.,F.G.Ijong dan T. Moniharapon, 2002, penilaian Indera. Penuntun Praktikum. Fakultas Perikanan dan Ilmu Kelautan. Unuversitas Sam Ratulangi, Manado.

Hanafiah K. A., 2002. Rancangan percobaan : Teori dan Aplikasi. Edisi ketiga. Divisi Buku Perguruan Tinggi. PT Raja Grafindo Persada, Jakarta.

Kinzel, B., 1992. Protein-Rich Edible Coatings For Food. Agricultural research.May $1992: 20-21$.

Riyanto B. 2006. Pengembangan Pelapis Edible Dari Isinglass Dan Aplikasinya Untuk Mempertahankan Mutu Udang Masak [tesis]. Bogor : Sekolah Pascasarjana, Institut Pertanian Bogor.

Santoso, E., Juwono, H., Ratnawati, Y. dan Rizal, R., 2007, "The isotherm adsorption of $\mathrm{Cu} 2+$ and $\mathrm{Cr} 3+$ ions in the aqueous solutions by cross-linked chitosan-cellulose membrane composite", Prosiding Seminar Nasional Kimia, Jurusan Kimia FMIPA ITS, Surabaya.

Suryaningrum, Th.D., Basmal, J. dan Nurochmawati. 2005. Studi Pembuatan Edible Film dari Karaginan. J. Penel. Perik. Idonesia 2 (4): 1-13 